\title{
The Role of Principal Leadership in Improving the Quality of Education
}

\author{
Widodo $^{1 *)}$, Yasir Arafat ${ }^{2}$, Dessy Wardiah ${ }^{2}$ \\ ${ }^{1}$ SD Negeri 15 Muara Telang \\ ${ }^{2}$ Universitas PGRI Palembang \\ *Corresponding author. Email: putrawidodo989@gmail.com
}

\begin{abstract}
The purpose of this study is to describe the principal's program to improve teacher professional competence, evaluation of school principals to improve teacher professional competence, and solutions to overcome obstacles in an effort to improve the quality of education. The method used in this research is qualitative research. The results of the principal's work program provide a positive climate for teachers and employees at SDN 15 Muara Telang where teachers provide ideas and input for the principal, add knowledge to classroom learning and apply it in learning, are active in making learning administration in schools, teachers are able to take advantage of information technology to support learning in the classroom. The forms of assignments are upgrading, KKG, and workshops, which are held by institutions/agencies outside of school. Barriers to improving the quality of education are incomplete facilities and infrastructure at schools and environmental factors. Solutions in improving the quality of education are cooperation and submitting proposals for additional facilities and infrastructure to the related education office.
\end{abstract}

Keywords: Competence, school principal, quality of education

\section{INTRODUCTION}

National education has the function of developing abilities and shaping the character and civilization of a nation with dignity in the framework of educating the nation's life, aiming "to develop the potential of students to become human beings who believe and have devotion to God Almighty, noble, healthy, knowledgeable, capable, creative, be independent and become a democratic and responsible citizen". "To make it happen, we need a competent educational institution to support the success of national functions and goals, one of which is a school" [1]

Education is a major factor in shaping human personality. "Even education has colored the journey of human life since humans were born until they can interact with their surroundings. Education is very instrumental in shaping the good or bad of the human personality in this life according to normative standards. On the other hand, education is a humanitarian process towards the birth of human beings with human values"[2]. "To prepare the golden generation of the Indonesian nation, school institutions at every level in Indonesia in general, and in South Sumatra, in particular, must continue to improve, strive to make innovations to adapt to the changes and developments of this modern era in the concept of mastery of science and technology according to the level of education" in elementary school.
The demand for quality improvement in the world of education is very important and is part of public accountability. "This is because, in the era of globalization, the management of the development sector is required to be carried out transparently and accountably to the public. The quality of education is deemed necessary to be improved by making improvements and changes in various sectors, especially management as part of efforts to improve the quality of education. Management of improving the quality of the school is one form of educational reform. The system is to offer schools to provide a better and adequate education for students. Management is a step for the school to improve the quality of the performance of teachers and units within the school in a planned, orderly, and sustainable manner. This includes offering community participation to take part in the management of improving the quality of schools"[3].

The quality of education will be achieved if it is supported by all components in well-organized education. "These components are input, process, output, teachers, facilities, infrastructure, costs, all of which need to get full support from parties who have an important role in educational institutions, in this case, the school principal. The principal is an educational leader who is directly related to the implementation of educational programs in schools. As a determinant of policies in schools, the principal 
must function to its full potential and be able to lead the school wisely and with direction, and lead to the achievement of maximum goals as well, to improve the quality of education"[3].

Improving the quality of schools is something that needs to be planned and implemented, in accordance with work goals and targets to be achieved based on the vision and mission, and objectives set within a certain period of time. "The principal has a very important role, and in school, management must be active, creative, innovative, and dare to take risks and be responsible. On an ongoing basis, School SelfEvaluation, situation analysis, and analysis of strengths, weaknesses, opportunities, and threats (SWOT analysis) must be carried out in managing the existing conditions in the school. The principal must strive for a system that can empower all school members in communication, compensation, evaluation, discipline, policy, personnel, selection, promotion, information, training, and career development. Through technical skills, he can describe how to do a job with his partners ". Must Communicate about plans, implementation, and work results effectively.

Within the scope of the school system "The principal has an important role in motivating teachers to work well. The principal should form a good managerial system with a clear task management system. A good managerial system can be formed by implementing the proper leadership functions of the Principal "[4]. "The principal is the key driving force for the development and progress of the school and is responsible for increasing the accountability for the success of students and their programs. In order for this to be achieved properly, the leadership of the principal needs to be empowered, so that the principal can play a role in accordance with his duties, authorities and responsibilities"[5].

Failure or success is determined by the leader, "because the leader is the controller and determinant of the direction that the institution wants to take towards the goals achieved. The direction taken by the institution towards the goal must be such that it optimizes the use of existing facilities and infrastructure "[6]. "The principal as the manager can be seen as a person who uses existing structures and procedures to achieve the goals of the school organization. The principal as a leader is seen as a person who makes changes"[7].

The principal is responsible for directing what is good and the principal himself must behave well because he is an example for his subordinates. "The principal is an example and is patient, understanding, and willing to accept input from his subordinates. The strategy for implementing activities is directed at the targets to be achieved, both in the short and long term. The choice of strategy is carried out by considering the current situation and conditions that have been predicted for the future. Time with predetermined goals is estimated for its relevance so that the implementation of a predetermined strategy does not make it difficult to achieve organizational goals"[8].

SDN 15 Muara Telang has the goal of realizing competitive and quality students and students have the basics of knowledge and abilities, skills to continue at a higher level. To achieve these noble goals, it is certain that the teachers in this school must have competent quality in accordance with government regulations. However, this will be difficult to materialize if there is no good leadership from the principal. The purpose of this study is to determine the role of principal leadership in improving the quality of education, obstacles to school leadership in managing school management to improve the quality of education, and solutions to overcome obstacles in an effort to improve the quality of education.

\section{METHODS}

The method used in this research was qualitative descriptive research [9]. With this descriptive qualitative research, the researcher tried to reveal the principal's leadership in improving the quality of education at the SDN 15 Muara Telang as it happened in the field, and tried to avoid the perspective of the researcher's subjectivity. The subjects in the study consisted of the principal, teachers, and students. The data collection techniques and procedures used the results of observations, interviews, and documentation. The data analysis were analysed qualitatively using coding, summarizing and concluding from the data gathering.

\section{RESULTS AND DISCUSSION}

\subsection{The Principal's Program in Improving the Quality of Teacher Education at SDN 15 Muara Telang}

The programs for improving the quality of teacher education implemented by school principals are as follows:

\subsubsection{Lesson study}

With the program of running this lesson study, there are groups or teacher learning communities at SDN 15 Muara Telang to carry out a detailed learning plan and there are learning interactions that contain the responses of students and teachers together with the teacher modifying plans and learning processes according to the evidence found in the field.

\subsubsection{Assignments}

Given the importance of the strategic role of teachers in every effort to improve the quality, relevance, and efficiency of education, increasing the professional ability of teachers is a necessity. 
"Therefore, one of the efforts that can be done is to increase the level of education to achieve ideal qualifications. The forms of assignment of school principals at SDN 15 Muara Telang are Upgrading, $K K G$, and workshops, which are held by institutions/agencies outside of school ", such as the education authorities.

The results of the assignments given by the principal to the teacher, from these assignments can be socialized in schools by opening meetings between teachers to follow up on the results of these assignments. With this meeting, all teachers at SDN 15 Muara Telang were affected by the assignment given by the school principal. The results of the assignment are in the form of workshops, training, and training programs that have been programmed by the Banyuasin education authority.

\subsection{Forms of Principal Strategies in Improving the Quality of Teacher Education at SDN 15 Muara Telang}

The strategies for developing the quality of teacher education at SDN 15 Muara Telang are as follows:

\subsubsection{Supervision}

Supervision is an aid in developing better teaching and learning situations in order to improve the quality of education. "In supervision, there are several main activities, that is continuous coaching, developing teacher professional abilities, improving teaching and learning situations, with the ultimate goal of achieving educational goals and the growth of students so that it has an impact on better education quality[10].

The objectives of educational supervision are as follows: (1) "fostering principals and teachers to better understand the real goals of education and the role of schools in achieving these goals; (2) enlarge the ability of school principals and teachers to prepare their students to become effective members of society; (3) Helping principals and teachers make a critical diagnosis of their activities and teaching and learning difficulties, and help them plan improvements; (4) increasing awareness of school principals and teachers and other school members of democratic and cooperative work procedures, and increasing willingness to help; (5) enlarging the ambition of teachers to improve the quality of their services maximally in their professional fields (expertise) to increase the "achievement motive" (6) helping school leaders to popularize schools to the community in developing educational programs; (7) helps principals and teachers to be able to evaluate their activities in the context of the development activities of students, and; (8) develop esprit de corps of teachers, which is a sense of unity and integrity "(collegiality) between teachers.

\subsubsection{Utilization of Information Technology}

The principal of SDN 15 Muara Telang is very concerned about the importance of the use of information technology, this school provides internet facilities so that teachers can access whatever is needed in order to increase their insight and knowledge. This will make teachers more developed, creative, and even make related innovations in teaching and learning.

Through information technology owned by the school, teachers can develop several things including:

\subsubsection{Learning Media}

The use of information technology as a learning medium can be done through "the use of the internet in e-learning and the use of computers as interactive media. It is hoped that the use of this media can stimulate the thoughts, feelings, interests, and attention of students in such a way that the learning process can occur. In addition, the learning process will be more effective because the use of instructional media allows for overcoming obstacles in the teacherstudent communication process such as physiological, psychological, cultural, and environmental".

At SDN 15 Muara Telang, technology is used as a program to improve the quality of education through the development of learning media. In the program, every teacher must be able to make learning media, and as little as possible, the teacher can operate a laptop and apply it in learning inside and outside the classroom

\subsubsection{E-learning}

The second program is the use of information technology, that is by e-learning. "E-learning is a form of information technology applied in education in virtual form. Through e-learning, learning is no longer limited by time and space. Learning can be done anywhere and anytime. Independent learning based on the creativity of students through e-learning encourages students to analyze and synthesize knowledge, explore, process, and utilize information, produce writing, information, and knowledge themselves. Students are installed to carry out scientific exploration. e-learning is carried out through the internet so that learning resources are not only teachers but also anyone in various parts of the world " [11].

\subsection{Obstacles Faced In Improving Quality of Education}

Inhibiting factors for the principal in improving the quality of education at SDN 15 Muara Telang, namely, incomplete facilities at school and environmental factors that are less supportive. 


\subsubsection{Incomplete facilities}

Incomplete facilities in schools such as libraries, laboratories, sports equipment, and connectivity (WIFI) that are used in the learning process inside and outside the classroom. This factor greatly hinders the principal in improving the quality of education in schools. This is based on the government's ability to equip facilities and infrastructure to support the learning process in schools. The government has completed manuals or textbooks but their utilization is still lacking, and WIFI in schools is only a certain point, and the connectivity is poor.

\subsubsection{Environmental factors}

SDN 15 Muara Telang is located in a water area with less favorable environmental conditions during the rainy season. In the rainy conditions, the roads are damaged (muddy) and are not supportive, so teachers are often late to come to school. So that in these conditions it can hinder the principal in improving the quality of education in schools.

\subsection{Solutions In Overcoming The Obstacles In Effort To Improve Education Quality}

To overcome the obstacles of school principals in improving the quality of education, solutions are needed, that is by cooperation and submitting proposals for additional facilities and infrastructure to the related education office.

\subsubsection{Mutual Cooperation}

The mutual cooperation of school supervisors with the school in realizing the vision and mission in schools becomes real action. With a cooperative relationship, the school relationship with the community in the school environment and the world of work can be strengthened, so that the principal can use it in introducing school programs to the community and the world of work regarding improving the quality of education.

\subsubsection{Submission of proposals for assistance to relevant agencies}

To complete the facilities and infrastructure at school, it is necessary to submit a proposal for assistance to the related agencies to complete facilities and infrastructure that are not available at school, so that the facilities and infrastructure for students and teachers will have an impact in improving the quality of learning for students.

\section{CONCLUSION}

From the results of the research, management, interpretation and analysis by the writer, regarding the Leadership of the Principal in improving the quality of education at SDN 15 Muara Telang, the writer can draw the conclusion that:
4.1 The school principal's program in improving the quality of education at SDN 15 Muara Telang was compiled jointly by involving all teachers and employees as well as the school committee so that the program that was compiled received support from all parties (stakeholders). The program implemented by the principal in improving the quality of education at SDN 15 Muara Telang is by forming lesson studies and assignments for the teachers.

4.2 Inhibiting factors for the principal in improving the quality of education at SDN 15 Muara Telang, that is incomplete infrastructure at schools and environmental factors that are less supportive.

4.3 The principal's solution in improving the quality of education is mutual cooperation and submitting proposals for additional facilities and infrastructure to the related education office.

\section{REFERENCES}

[1] A. Tuti. (2019). Peran Kepala Sekolah Perempuan Dalam Upaya Peningkatan Mutu Pendidikan di Sekolah Dasar Muhammadiyah 01 Pekanbaru. POTENSIA: Jurnal Kependidikan Islam, Vol. 5, No. 1, Januari - Juni 2019. Universitas Islam Negeri Sultan Syarif Kasim Riau.

[2] Sonedi, S., \& Tutut, D. (2018). Peran Kepemimpinan Kepala Sekolah dalam Meningkatkan Kinerja Guru. Anterior Jurnal, Volume 18 Issue 1, December 2018, Page 13 22 p-ISSN: 1412-1395; e-ISSN: 2355-3529.

[3] Juliantoro, M. (2017). Peran Kepala Sekolah dalam Meningkatkan Mutu Pendidikan. Jurnal al-Hikmah vol. 5 no. 2 Oktober 2017.

[4] M. Susti, A. Syarwani, E. Syaiful. (2020). Manajemen Kepemimpinan Kepala Sekolah Sebagai Administrator Dalam Peningkatan Kompetensi Guru. Dawuh: Islamic Education Jurnal Vol. 1, No. 2, Juli 2020. Universitas PGRI Palembang.

[5] Fitrah, M. (2017). Peran Kepala Sekolah Dalam Meningkatkan Mutu Pendidikan. Jurnal Penjaminan Mutu 3(1) 2017. Institut Agama Islam Muhammadiyah Bima.

[6] M Anik \& K. H. Arghob. (2019). Peran Kepala Sekolah Dalam Meningkatkan Manajemen Mutu Pendidikan di Madrasah Ibtidaiyah. Quality Volume 7, Nomor 2, 2019. IAIN Kudus.

[7] Wardani, A. (2013). Peran Kepemimpinan Kepala Sekolah Perempuan Terhadap Motivasi Kerja Guru (Studi di SMA N 12 Semarang). UCEJ Unnes Civic Education Journal 2 (2) (2013). Universitas Negeri Semarang. 
[8] I. Herni dan W. Dessy. (2017). Manajemen Strategis Kepala Sekolah Dalam Upaya Menarik Minat Calon Peserta Didik di SMP IT Ar-Ridho Palembang. JMKSP: Jurnal Manajemen, Kepemimpinan, dan Supervisi Pendidikan Volume 2, No. 1, Januari-Juni 201733. Universitas PGRI Palembang.

[9] Sugiyono, (2010). Metode Penelitian Kualitatif, Kuantitatif dan RD. Bandung: Alfabeta.

[10] Mardalena, A. Yasir, F. Happy. (2020). Pengaruh Supervisi Akademik dan Kompetensi
Profesional Guru terhadap Kinerja Guru di Sekolah Menengah Atas Negeri di Kecamatan Tanjung Raja. Jurnal Intelektualita: Keislaman, Sosial, dan Sains Vol. 9, No. 1, Juni 2020 ISSN 2303-2952, e-ISSN 2622-8491. Universitas PGRI Palembang, Indonesia

[11]Husaini M. (2014). Pemanfaatan Teknologi Informasi Dalam Bidang Pendidikan (EEducation). Jurnal Mikrotik Volume 2 No.1Bulan Mei 2014. IAIN Raden Intan Lampung. 